\title{
Integral valorization of vine pruning residue by sequential autohydrolysis stages
}

\author{
Meirielly S. Jesus ${ }^{1}$, Aloia Romaní ${ }^{1}$, Zlatina Genisheva, José A. Teixeira, Lucília Domingues* \\ CEB-Centre of Biological Engineering, University of Minho, Campus Gualtar, Braga, Portugal
}

\section{A R T I C L E I N F O}

\section{Article history:}

Received 25 February 2017

Received in revised form

24 August 2017

Accepted 25 August 2017

Available online 3 September 2017

\section{Keywords:}

Vine pruning residue

Hydrothermal treatment

Oligosaccharide

Bioethanol

Phenolic compound

\begin{abstract}
A B S T R A C T
Wine processing generates a large amount of residue, in particular pruning residue of vine. In this work, autohydrolysis in two sequential stages was proposed for the integral valorization of this residue. In a first stage, vine pruning residue was submitted to autohydrolysis treatment at $180^{\circ} \mathrm{C}$ for $60 \mathrm{~min}$ (severity of 4.13) and liquid to solid ratio of $6 \mathrm{~g}$ water per $\mathrm{g}$ vine pruning residue. In these conditions, $63.7 \% \mathrm{of}$ xylan was recovered in the liquid phase as xylooligosaccharides $(17 \mathrm{~g} / \mathrm{L})$ and $2.35 \mathrm{~g} / \mathrm{L}$ of phenolic compounds with antioxidant activity were also extracted. Autohydrolyzed vine pruning residue was subjected to a second autohydrolysis at temperature in the range $180-200{ }^{\circ} \mathrm{C}$ and time $30-40 \mathrm{~min}$. After sequential treatments, enzymatic hydrolysis of cellulose was significantly improved from $73 \%$ to $99 \%$ of conversion. At selected conditions (severity of 4.60), ethanol production was successfully obtained from two strategies of, separately and simultaneously, saccharification and fermentation, thus achieving ethanol yield of 96 and $83 \%$, respectively. Overall, two sequential stages of the process allowed the recovery of $13.7 \mathrm{~kg}$ of xylooligosaccharides, $3.1 \mathrm{~kg}$ of phenolic compounds, $13.1 \mathrm{~kg}$ of ethanol and $27 \mathrm{~kg}$ of lignin per $100 \mathrm{~kg}$ of vine pruning residue. Sequential autohydrolysis stages were shown as a suitable strategy for the integral valorization of vine pruning residue.
\end{abstract}

๑) 2017 Elsevier Ltd. All rights reserved.

\section{Introduction}

The bioeconomy is based on the optimal use of renewable resources (such as lignocellulosic biomass) through the development of biorefineries for the co-production of fuels and high-value biobased products as chemicals and materials (Hennig et al., 2016; Karlsson et al., 2014). In particular, high-value bio-based products are obtained by a sustainable process based on principles of green chemistry (Peleteiro et al., 2014).

Lignocellulosic biomass includes wastes from agriculture, forestry and related industries (Ferreira et al., 2009). In Portugal, the wine industry generates during wine processing a lot of residues (such as vine pruning residue, VPR) with an estimated annual production of 1.2-3.5 t/ha (Brito et al., 2014). These residues are typically left in the agricultural field, used as domestic fuel due to calorific power or burnt in the field which causes environmental

\footnotetext{
* Corresponding author.

E-mail addresses: meirielly@ceb.uminho.pt (M.S. Jesus), aloia@ceb.uminho.pt (A. Romaní), zlatina@deb.uminho.pt (Z. Genisheva), jateixeira@deb.uminho.pt (J.A. Teixeira), luciliad@deb.uminho.pt (L. Domingues).

${ }^{1}$ Both authors contributed equally to the work.
}

pollution (Devesa-Rey et al., 2010). The potential energy that these residues could provide has been estimated in $190 \mathrm{GW}$ per year or alcohol equivalent of 357 million liters (Ferreira et al., 2009). The Portuguese experience is limited to combustion of biomass. Nevertheless, VPR is a lignocellulose biomass enriched with biobased compounds with potential to be transformed into commercial products by selective fractionation of the main components (cellulose, hemicellulose and lignin) (Dávila et al., 2016). Therefore, the valorization of these residues under a biorefinery approach could contribute attaining an energy and rural sustainable development (Lin et al., 2014).

Several pretreatments have been proposed for the processing of vine pruning residue, such as alkali pretreatment for glucose production (Cotana et al., 2015), enzymatic hydrolysis and ultrasounds pretreatments to obtain methane and biogas (Pérez-Rodríguez et al., 2016), or ethylene glycol pulping for paper sheets manufacturing (Jiménez et al., 2008). Recently, hydrothermal treatment (known as autohydrolysis) has been used for xylooligosaccharides (Dávila et al., 2016) and ethanol production (Buratti et al., 2015). Moreover, this residue is enriched in polyphenolic compounds (Max et al., 2010; Pérez-Rodríguez et al., 2016) with potential antioxidant features. Autohydrolysis has also been 


\begin{tabular}{|c|c|c|c|}
\hline \multicolumn{2}{|c|}{ Nomenclature } & $E_{a}$ & Activation energy $(\mathrm{J} / \mathrm{mol})$ \\
\hline \multicolumn{2}{|c|}{ Abbreviations } & $\mathrm{EtOH}_{0}$ & $\begin{array}{l}\text { Ethanol concentration at the beginning of the } \\
\text { fermentation }(\mathrm{g} / \mathrm{L})\end{array}$ \\
\hline $\begin{array}{l}\text { ABTS } \\
\text { ATR }\end{array}$ & $\begin{array}{l}\text { 2,2'-azino-bis-3-ethylbenzthiazoline-6-sulphonic acid } \\
\text { Attenuated total reflectance }\end{array}$ & $\mathrm{EtOH}_{f}$ & $\begin{array}{l}\text { Ethanol concentration at the end of the fermentation } \\
(\mathrm{g} / \mathrm{L})\end{array}$ \\
\hline $\mathrm{DPPH}$ & 2,2-diphenyl-1-picryl-hydrazyl-hydrate & $F$ & Glucan fraction in dry biomass ( $\mathrm{g}$ per $\mathrm{g}$ ) \\
\hline DTG & Derivative Thermogravimetric & G & Glucose concentration $(\mathrm{g} / \mathrm{L})$ \\
\hline FPU & Filter Paper Units & GGC & Glucan to glucose conversion (\%) \\
\hline FT-IR & Fourier-transform infrared & Ia & Inhibition activity $(\%)$ \\
\hline GAE & Gallic Acid Equivalent & $I C_{50}$ & Concentration of sample or standard that can inhibit \\
\hline$H M F$ & Hydroxymethylfurfural & & $50 \%$ of $\mathrm{DPPH}$ or ABTS $(\mathrm{mg} / \mathrm{mL})$ \\
\hline HPLC & High-performance Liquid Chromatography & $L S R$ & Liquid to solid ratio ( $\mathrm{g}$ per $\mathrm{g}$ ) \\
\hline SEM & Scanning Electron Microscopy & $R$ & Ideal gas constant $(\mathrm{J} / \mathrm{mol} \mathrm{K})$ \\
\hline SHF & Separate Hydrolysis and Fermentation & $R_{0}$ & Reaction ordinate (min) \\
\hline SSF & Simultaneous Saccharification and Fermentation & $S_{0}$ & Severity (dimensionless) \\
\hline TAPPI & Technical Association of the Pulp and Paper Industry & SY & Solid yield (g autohydrolyzed VPR per $100 \mathrm{~g}$ of VPR, \\
\hline TGA & Thermogravimetric Analysis & & oven dry basis) \\
\hline UHPLC & Ultra-high-performance liquid chromatography & $T_{(t)}$ & Represent the temperature profile in the heating stage \\
\hline$U I$ & Unit International & & $(\mathrm{K})$ \\
\hline VPR & Vine Pruning Residue & $T_{(t)}^{\prime}$ & $\begin{array}{l}\text { Represent the temperature profile in the cooling stage } \\
(\mathrm{K})\end{array}$ \\
\hline \multicolumn{2}{|c|}{ Parameters and constants } & $t_{F}$ & Time needed for the whole heating-cooling period \\
\hline$\Omega$ & Empirical parameter $(14.75 \mathrm{~K})$ & & $(\min )$ \\
\hline$A_{0}$ & Absorbance of control (DPPH or ABTS) & $T_{M A X}$ & Target temperature $(\mathrm{K})$ \\
\hline$A_{1}$ & Absorbance of autohydrolysis liquor & $t_{M A X}$ & Time needed to achieve the target temperature ( $\mathrm{min}$ ) \\
\hline$B$ & Biomass concentration $(\mathrm{g} / \mathrm{L})$ & $T_{R E F}$ & Reference temperature $(373.15 \mathrm{~K})$ \\
\hline C & Cellobiose concentration $(\mathrm{g} / \mathrm{L})$ & $Y_{E t}$ & Ethanol yield $(\%)$ \\
\hline
\end{tabular}

proposed for the extraction of phenolic compounds from lignocellulosic biomass (Egüés et al., 2012). Therefore, autohydrolysis is considered a green and sustainable technology suitable to be used in lignocellulosic biorefineries (Gullón et al., 2012). Yet, an integrated approach for the valorization of whole biomass fractions is mandatory to achieve a cost-competitive process (Singhvi et al., 2014). In this sense, one of the autohydrolysis limitations is the difficulty to attain an optimal condition for oligosaccharides manufacturing and suitable saccharification of cellulose into glucose for fuel production (Romaní et al., 2010). Typically, cellulose is more prone to saccharification after harsh conditions of pretreatment while in these severe conditions the xylose and xylooligosaccharides are degraded into sugars and/or inhibitors compounds such as furfural (Guilliams et al., 2016). Thus, the strategy employed for this two-target goal usually includes the use of two treatments (such as an autohydrolysis combined with a delignification process) (Romaní et al., 2011, 2016). Delignification processes solubilize the lignin and, consequently, the solid fraction is enriched in glucan being more susceptible to enzymatic hydrolysis (Romaní et al., 2011). Nevertheless, delignification treatments use alkalis and organic solvents, demanding additional steps of washing and neutralization. Moreover, the handling of these chemicals is less safe (Chaturvedi and Verma, 2013). As alternative to delignification process, autohydrolysis in two sequential stages at milder conditions (with water as only catalyst) is shown as an attractive and cleaner solution to disrupt lignocellulosic matrix attaining a suitable recovery of all its components or derivatives (Lee et al., 2010; Min et al., 2015).

In this study, a process using autohydrolysis in two sequential stages was used for the fractionation and integral valorization of VPR. The conditions of operation (temperature and time, severity in the range of 3.36-4.90) were evaluated in order to maximize the hemicellulose-derived compounds recovery (as oligosaccharides) and for quantification and identification of phenolic compounds in autohydrolysis liquor. Moreover, an alternative second autohydrolysis of pretreated solid from the first autohydrolysis was carried out (severity in the range of 4.36-4.69) to improve the enzymatic accessibility of cellulose for glucose production and further fermentation into ethanol by simultaneous and separate saccharification and fermentation (SSF and SHF, respectively).

\section{Materials and methods}

\subsection{Raw material and analysis of chemical composition}

Vine pruning residue was provided from a local producer from Minho region, Northern Portugal. VPR was air-dried, milled to pass an $8 \mathrm{~mm}$ screen, homogenized in a single lot to avoid differences in the composition, and stored at room temperature in a dark and dry place until use. The raw material was analyzed by TAPPI (Technical Association of the Pulp and Paper Industry) standards for extractives, moisture, ashes and quantitative acid hydrolysis with $72 \%(\mathrm{w} /$ w) sulphuric acid (T-264-cm-07; T-211-cm-93; T-249-em-85). VPR was Soxhlet extracted with water and ethanol as described in Romaní et al. (2016). Liquors from quantitative acid hydrolysis and aqueous extract were analyzed by High-Performance Liquid Chromatography (HPLC) for sugars (glucose, xylose, arabinose) and acetic acid, using a Refractive Index detector and an $87 \mathrm{H}$ $(300 \times 7.8 \mathrm{~mm})$ Aminex (BioRad) column eluted with $0.005 \mathrm{M}$ $\mathrm{H}_{2} \mathrm{SO}_{4}$, flow rate of $0.6 \mathrm{~mL} / \mathrm{min}$ at $60{ }^{\circ} \mathrm{C}$. The content of polysaccharides (glucan, xylan, arabinan) and acetyl groups was calculated from HPLC data. The Klason lignin content of VPR was gravimetrically measured from the insoluble solid residue obtained after the quantitative acid hydrolysis step. 
2.2. Autohydrolysis of vine pruning residue in two sequential stages: solid and liquid characterization

\subsubsection{First autohydrolysis stage}

$$
\begin{aligned}
& S_{0}= \log R_{0}=\log \left(R_{0} \text { HEATING }+R_{0} \text { COOLING }\right) \\
&=\log \left[\int_{0}^{t_{\text {MAX }}} \exp \left(\frac{\mathrm{T}(\mathrm{t})-T_{R E F}}{\omega}\right) \mathrm{dt}\right] \\
&+\left[\int_{t_{\text {MAX }}}^{t_{F}} \exp \left(\frac{\mathrm{T}(\dot{\mathrm{t}})-T_{R E F}}{\omega}\right) \mathrm{dt}\right]
\end{aligned}
$$

The VPR was submitted to autohydrolysis treatments under conditions listed in Table 1. For this, water was mixed with VPR at liquid to solid ratio (LSR) of $8 \mathrm{~g}$ per $\mathrm{g}$, placed in stainless steel reactor and submerged in silicone oil bath in a $160 \mathrm{~mL}$ total volume batch cylinder reactor fabricated from 316 stainless steel at distinct temperatures $\left(180-200{ }^{\circ} \mathrm{C}\right)$ and different reaction times (10-90 $\mathrm{min}$ ) (heating time of $5 \mathrm{~min}$ ). After autohydrolysis treatment, the reactor was removed from the oil bath and cooled down in an ice-water bath for $5 \mathrm{~min}$. The hardness of autohydrolysis treatments can be expressed in terms of "severity" $\left(S_{0}\right)$ (Lavoie et al., 2010), defined as the logarithm of the reaction ordinate $\left(R_{0}\right)$ (Overend and Chornet, 1987; Abatzoglou et al., 1992), which was calculated using the following equation:

According to this expression, $R_{0}$ is the reaction ordinate (min), $t_{\text {MAX }}(\mathrm{min}$ ) is the time needed to achieve the target temperature $T_{\text {MAX }}(\mathrm{K}), t_{F}(\mathrm{~min})$ is the time needed for the whole heating-cooling period, $T(t)$ and $T^{\prime}(t)$ represent the temperature profiles in the heating and cooling stages $(\mathrm{K})$, respectively, $T_{R E F}$ is the reference temperature $\left(\mathrm{T}_{\mathrm{REF}}=373.15 \mathrm{~K}\right)$ and $\omega$ is an empirical parameter related with the activation energy of hemicellulose solubilization reaction, which can be expressed as (Garrote et al., 2002):

$\omega=\frac{R T_{R E F^{2}}}{E_{a}}$

where, $R$ is the ideal gas constant $(R=8.314 \mathrm{~J} / \mathrm{mol} \mathrm{K})$ and $E_{a}$ is the activation energy of hemicellulose solubilization reaction in $\mathrm{J} / \mathrm{mol}$. Although $\omega$ can be evaluated and optimized (Garrote et al., 2002), it is common to select a value of $\omega=14.75 \mathrm{~K}$ (González-Muñoz et al., 2011).

After autohydrolysis treatment, solid and liquid phases were separated by filtration for determination of chemical composition. An aliquot of autohydrolysis liquors (liquid phase) was filtered through $0.45 \mu \mathrm{m}$ membranes and used for direct HPLC determination of glucose, xylose, arabinose, acetic acid, hydroxymethylfurfural (HMF) and furfural, using the same method specified above. A second aliquot was subjected to quantitative post hydrolysis with $4 \%(\mathrm{w} / \mathrm{w})$ sulphuric acid at $121{ }^{\circ} \mathrm{C}$ for $30 \mathrm{~min}$, filtered through $0.45 \mu \mathrm{m}$ membranes, and analyzed by HPLC for oligosaccharides concentration.

Solid phase from autohydrolysis was washed with distilled water, air-dried and employed for solid yield (SY) determination (expressed as g autohydrolyzed VPR per $100 \mathrm{~g}$ VPR, oven dry basis). Pretreated VPR was analyzed for glucan, xylan and Klason lignin using the analytical procedure described in section 2.1 .

\subsubsection{Second autohydrolysis stage}

Second autohydrolysis treatment was performed mixing water and pretreated VPR from first autohydrolysis (Fig. 1) at LSR of $6 \mathrm{~g}$ per $g$. Conditions of the second stage of autohydrolysis were listed

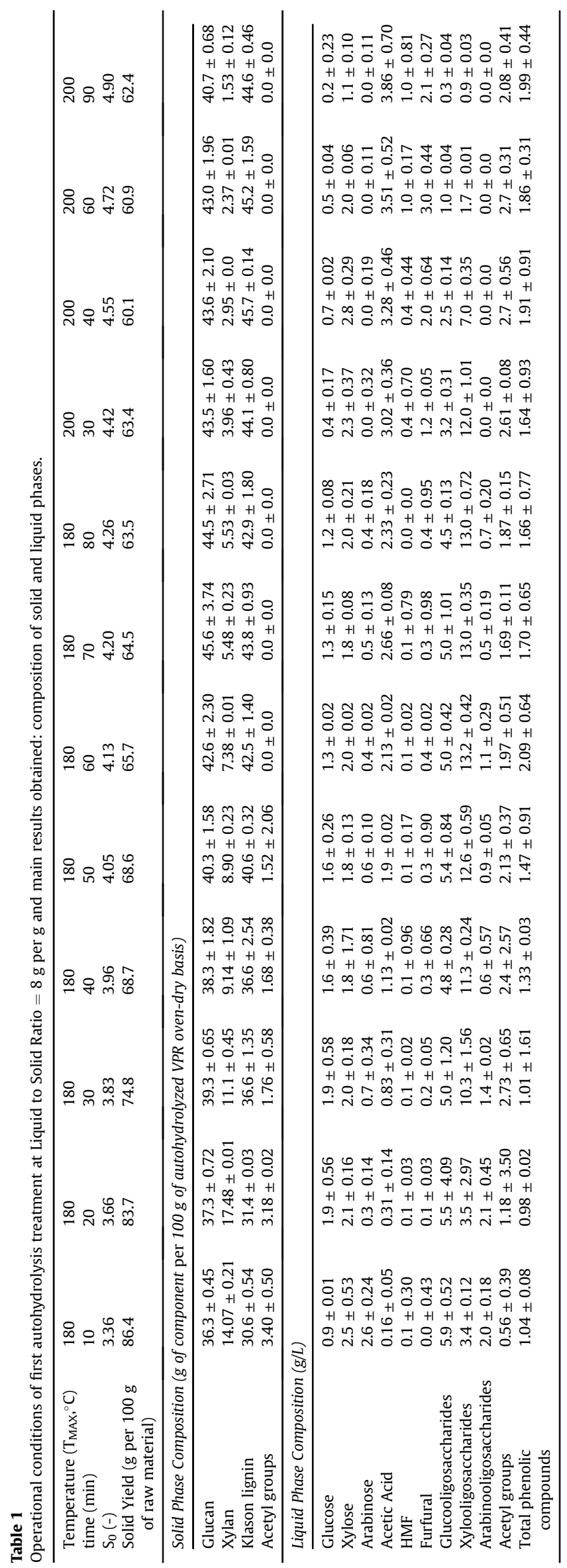




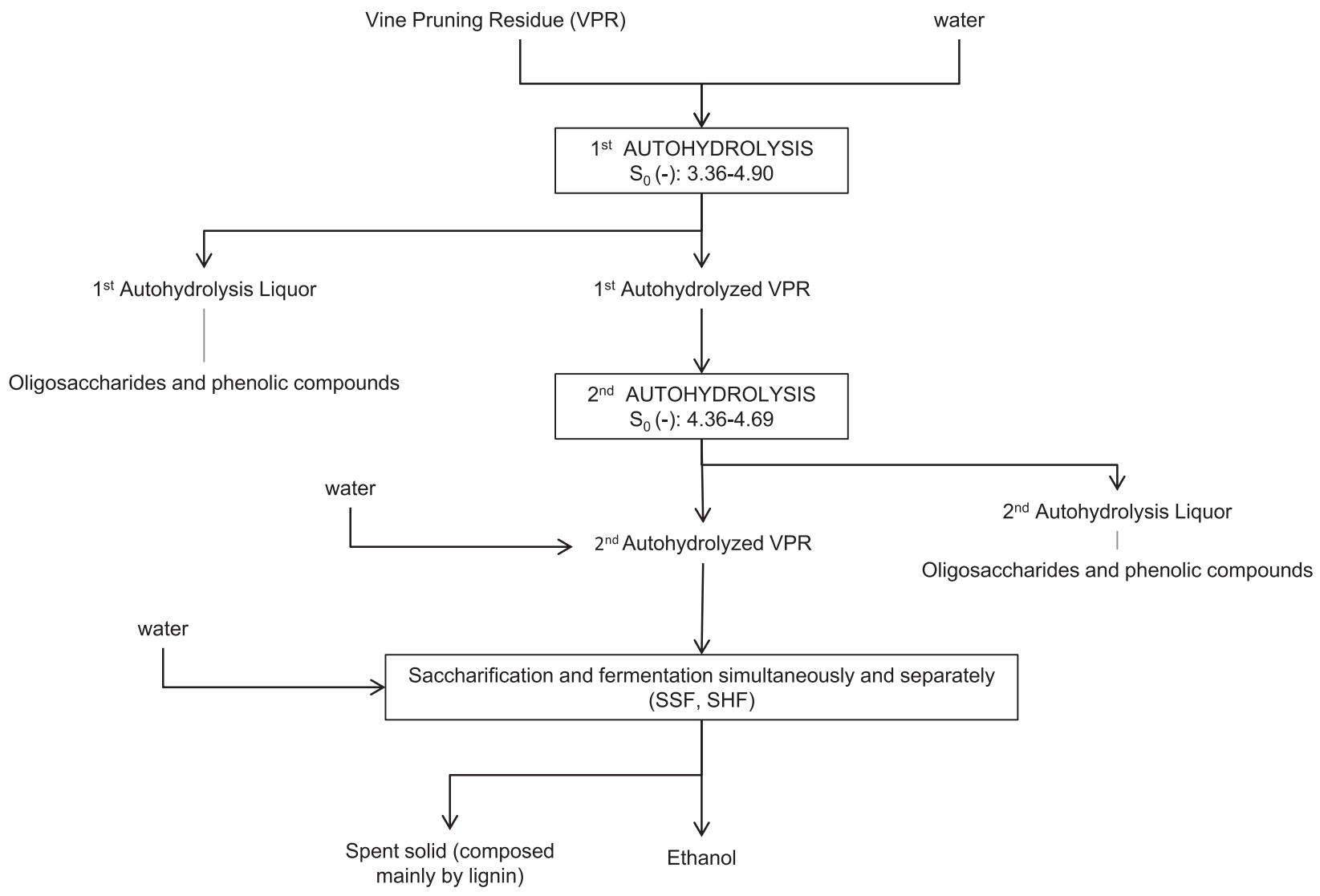

Fig. 1. Scheme proposed in this work for integral valorization of vine pruning residue.

in Table 2 and carried out at LSR of $6 \mathrm{~g}$ per $\mathrm{g}$.

\subsection{Phenolic compounds analysis and antioxidant activity of autohydrolysis liquors}

Autohydrolysis liquors were analyzed for total phenolic compounds (expressed as gallic acid equivalents, GAE) by absorbance following Folin-Ciocalteu method (as described in Conde et al., 2011). In addition, some phenolic compounds were also identified by Ultra-high-performance liquid chromatography (UHPLC) using a Shimatzu Nexpera X2 UHPLC chromatograph equipped with Diode Array Detector (Shimadzu, SPD-M20A). Separation was performed on a reversed-phase Acquity UHPLC BEH C18 column $\left(2.1 \mathrm{~mm} \times 100 \mathrm{~mm}, 1.7 \mu \mathrm{m}\right.$ particle size; from Waters) at $40{ }^{\circ} \mathrm{C}$. The flow rate was $0.4 \mathrm{~mL} / \mathrm{min}$. The HPLC grade solvents used were water/formic acid $(0.1 \%)$ as solvent $\mathrm{A}$ and acetonitrile as solvent $\mathrm{B}$. The elution gradient for solvent $B$ was as follows: from 0.0 to $5.5 \mathrm{~min}$ at $5 \%$, from 5.5 to $17 \mathrm{~min}$ a linear increase to $60 \%$, from 17.0 to $18.5 \mathrm{~min}$ a linear increase to $100 \%$, then column equilibration from 18.5 to $30.0 \mathrm{~min}$ at $5 \%$.

Antioxidant activity of autohydrolysis liquors was also determined by 2,2-diphenyl-1-picrylhydrazyl (DPPH) radical scavenging activity assay and the radical cation decolorization of 2,2'-azinobis(3-ethylbenzothiazoline-6-sulphonic acid) (ABTS) assay following the methods described in Karacabey et al. (2012) and Ballesteros et al. (2015). The percentage of inhibition was calculated as a function of the concentration of autohydrolysis liquor and Trolox. $I C_{50}$ (concentration of sample required to reduce $50 \%$ of DPPH or ABTS) was calculated by interpolation of the inhibition activity (Ia, \%), calculated by the following equation:
Ia $=\frac{A_{0}-A_{1}}{A_{1}} 100$

where $A_{0}$ is the absorbance of the control (DPPH or ABTS), and the $A_{1}$ is the absorbance of the autohydrolysis liquor.

\subsection{Enzymatic hydrolysis of vine pruning residue from autohydrolysis treatment}

In order to evaluate the enzymatic susceptibility of leftover glucan in pretreated vine pruning residue, enzymatic hydrolysis assays were carried out using commercial enzymes Cellic Ctec2 (cellulase) and Htec2 (hemicellulase), kindly provided by Novozymes (Denmark). Enzymatic activities for cellulases and hemicellulases were determined (Ghose, 1987; Bailey et al., 1992) corresponding to 120 Filter Paper Unit (FPU)/mL and 1690 International Unit (IU)/mL, respectively. The enzymatic hydrolysis was carried out in an orbital shaker at $50{ }^{\circ} \mathrm{C}$ and $150 \mathrm{rpm}$ using $4 \%$ and $10 \%$ of solids and enzyme loading of 25 FPU per $g$ of substrate in a $0.05 \mathrm{~N}$ sodium citrate buffer ( $\mathrm{pH} 4.85$ ). Samples were withdrawn between $0-72 \mathrm{~h}$ and analyzed by HPLC for glucose and xylose concentration. All determinations were performed in duplicate. The results obtained from enzymatic hydrolysis can also be expressed as glucan to glucose conversion (GGC, \%) using the following equation:

$G G C=\frac{G+1.053 C}{1.111 f B} 100$

where, $G$ is glucose concentration $(\mathrm{g} / \mathrm{L}), \quad C$ is cellobiose 
Table 2

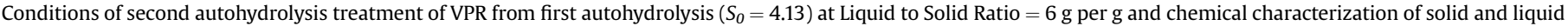
phases (first and second autohydrolysis stages).

\begin{tabular}{|c|c|c|c|c|c|}
\hline \multirow{3}{*}{$\begin{array}{l}\text { Temperature }\left(\mathrm{T}_{\mathrm{MAX}},{ }^{\circ} \mathrm{C}\right) \\
\text { time }(\min )\end{array}$} & \multirow{2}{*}{$\frac{\text { 1st Stage Autohydrolysis }}{180}$} & \multicolumn{4}{|c|}{ 2nd Stage Autohydrolysis } \\
\hline & & 180 & 180 & 200 & 200 \\
\hline & 60 & 40 & 60 & 30 & 40 \\
\hline$S_{0}(-)$ & 4.13 & 3.96 & 4.13 & 4.42 & 4.55 \\
\hline Total $S_{0}^{\mathrm{a}}(-)$ & - & 4.36 & 4.43 & 4.60 & 4.69 \\
\hline Solid Yield & 66.02 & 66.60 & 62.01 & 62.61 & 63.60 \\
\hline Solid phase composition & (g per $100 \mathrm{~g}$ of $1 \mathrm{st}$ autohydrolyzed VPR) & \multicolumn{4}{|c|}{ (g per $100 \mathrm{~g}$ of 2 nd autohydrolyzed VPR) } \\
\hline Glucan & $41.31 \pm 3.58$ & $40.40 \pm 0.46$ & $41.35 \pm 1.70$ & $41.72 \pm 0.98$ & $40.35 \pm 0.59$ \\
\hline Xylan & $9.96 \pm 2.44$ & $6.98 \pm 0.16$ & $6.58 \pm 0.20$ & $6.29 \pm 0.12$ & $4.28 \pm 0.08$ \\
\hline Klason Lignin & $42.20 \pm 0.69$ & $40.05 \pm 3.83$ & $40.11 \pm 0.53$ & $40.55 \pm 2.45$ & $39.58 \pm 4.17$ \\
\hline Liquid phase composition & $(\mathrm{g} / \mathrm{L})$ & \multicolumn{4}{|l|}{$(\mathrm{g} / \mathrm{L})$} \\
\hline Glucose & $1.50 \pm 0.79$ & $0.11 \pm 0.02$ & $0.14 \pm 0.15$ & $0.14 \pm 0.03$ & $0.17 \pm 0.04$ \\
\hline Xylose & $1.99 \pm 0.93$ & $0.53 \pm 0.01$ & $0.81 \pm 0.34$ & $1.18 \pm 0.03$ & $1.47 \pm 0.60$ \\
\hline Arabinose & $0.72 \pm 0.21$ & $0.11 \pm 0.01$ & $0.10 \pm 0.62$ & $0.12 \pm 0.02$ & $0.09 \pm 0.09$ \\
\hline Acetic Acid & $0.96 \pm 1.06$ & $0.59 \pm 0.09$ & $0.84 \pm 0.77$ & $0.98 \pm 0.04$ & $1.45 \pm 0.24$ \\
\hline Furfural & $0.36 \pm 0.27$ & $0.42 \pm 0.02$ & $1.07 \pm 0.67$ & $0.99 \pm 0.54$ & $1.24 \pm 0.52$ \\
\hline HMF & $0.66 \pm 0.42$ & $0.82 \pm 0.01$ & $2.47 \pm 1.64$ & $3.08 \pm 0.88$ & $4.50 \pm 0.12$ \\
\hline Glucooligosaccharides & $6.29 \pm 0.63$ & $0.61 \pm 0.01$ & $0.55 \pm 0.01$ & $0.68 \pm 0.02$ & $0.57 \pm 0.04$ \\
\hline Xylooligosaccharides & $17.22 \pm 0.73$ & $5.20 \pm 0.01$ & $5.50 \pm 0.02$ & $6.88 \pm 0.12$ & $4.89 \pm 0.09$ \\
\hline Arabinooligosaccharides & $1.60 \pm 0.56$ & $0.0 \pm 0.0$ & $0.0 \pm 0.0$ & $0.0 \pm 0.0$ & $0.0 \pm 0.0$ \\
\hline Acetyl groups & $6.10 \pm 0.30$ & $1.74 \pm 0.03$ & $1.64 \pm 0.02$ & $2.17 \pm 0.09$ & $1.82 \pm 0.02$ \\
\hline
\end{tabular}

${ }^{\text {a }}$ Total $S_{0}$ was calculated taking into account the severity of first stage and second.

concentration $(\mathrm{g} / \mathrm{L}), B$ is dry biomass concentration $(\mathrm{g} / \mathrm{L}), f$ is glucan fraction in dry biomass ( $\mathrm{g}$ per $\mathrm{g}$ ), the multiplication factor, 1.053, converts cellobiose to equivalent glucose and 1.111 is the stoichiometric factor that converts glucan to equivalent glucose. In all experiments, cellobiose was not detected.

\subsection{Inoculum preparation}

Yeast used in this work was Saccharomyces cerevisiae PE-2 strain (isolated from Brazilian Bioethanol Distillery) (Pereira et al., 2014). Stock culture was maintained on yeast peptone dextrose medium ( $2 \%$ of glucose, $2 \%$ of peptone and $1 \%$ of yeast extract) agar plates at $4{ }^{\circ} \mathrm{C}$. Yeast was grown in Erlenmeyer flasks containing $20 \mathrm{~g} / \mathrm{L}$ of glucose, $20 \mathrm{~g} / \mathrm{L}$ of peptone and $10 \mathrm{~g} / \mathrm{L}$ of yeast extract for $15 \mathrm{~h}$ at $30{ }^{\circ} \mathrm{C}$ and $200 \mathrm{rpm}$. Cells were separated from culture media by centrifugation ( $10 \mathrm{~min}$ at $4{ }^{\circ} \mathrm{C}$ and $7500 \mathrm{~g}$ ) and resuspended in $0.9 \%$ $\mathrm{NaCl}$. Simultaneous saccharification and fermentation (SSF) and separate hydrolysis and fermentation (SHF) experiments were inoculated with $5 \mathrm{mg}$ of fresh yeast per $\mathrm{mL}$ (final concentration).

\subsection{Saccharification and fermentation}

For ethanol production, separate and simultaneous saccharification and fermentation assays (SHF and SSF) were carried out using as substrate the pretreated VPR obtained from autohydrolysis in two sequential stages (Fig. 1). Enzymes used for saccharification were Cellic Ctec2 and Cellic Htec2. Nutrients (peptone and yeast extract) were sterilized in autoclave separately from pretreated VPR at $121{ }^{\circ} \mathrm{C}$ for $15 \mathrm{~min}$. Inoculum and enzymes were added to SSF assays. Experiments were carried out at $35^{\circ} \mathrm{C}$ and $150 \mathrm{rpm}$. For SHF assays, enzymatic hydrolysis (at $50{ }^{\circ} \mathrm{C}$ ) was carried out for $48 \mathrm{~h}$. After this, temperature was decreased to $30^{\circ} \mathrm{C}$ and yeast cells were added. Samples from SHF and SSF were withdrawn at desired times and analyzed by HPLC for ethanol concentration. Ethanol yield $\left(Y_{E t}\right)$ was calculated by the following equation:

$Y_{E t}=\frac{\mathrm{EtOH}_{\mathrm{f}}-\mathrm{EtOH}_{0}}{0.5 \mathrm{l} f \mathrm{B1.111}} 100$ where, $\mathrm{EtOH}_{f}$ is the ethanol concentration produced during the fermentation $(\mathrm{g} / \mathrm{L}), \mathrm{EtOH}_{o}$ is the ethanol concentration at the beginning of the fermentation $(\mathrm{g} / \mathrm{L})$ which was zero, $B$ is dry biomass concentration at the beginning of the fermentation $(\mathrm{g} / \mathrm{L}), f$ is glucan fraction of dry biomass ( $\mathrm{g}$ per $\mathrm{g}$ ), 0.51 is conversion factor for glucose to ethanol based on stoichiometric biochemistry of yeast. The stoichiometric factor that converts glucan to equivalent glucose is 1.111 .

\subsection{Structural analysis of raw material and pretreated samples}

\subsubsection{Scanning electron microscopy (SEM) analysis}

Micrographs of raw material, autohydrolyzed vine pruning residue from the first autohydrolysis $\left(180^{\circ} \mathrm{C}\right.$ for $\left.60 \mathrm{~min}, S_{0}=4.13\right)$ and autohydrolyzed vine pruning residue from the second autohydrolysis $\left(200{ }^{\circ} \mathrm{C}\right.$ for $\left.30 \mathrm{~min}, S_{0}=4.60\right)$ were obtained using a desktop scanning electron microscope (Phenom-World BV, Netherlands). The images were obtained using a voltage of $5 \mathrm{kV}$ at 270-fold magnification.

\subsubsection{Thermal analysis of spent residue recovered after SHF assay}

Thermogravimetric analysis (TGA) of spent residue recovered after saccharification and fermentation assay was carried out in Thermogravimetric (TGA 4000 and DSC 6000) Analyzer. The analysis was carried out in the range of $25-600^{\circ} \mathrm{C}$ with a linear increase of $10^{\circ} \mathrm{C}$ per min.

\subsubsection{Fourier-transform infrared (FT-IR)}

The chemical groups and bonding arrangement of constituents of the spent residue obtained after saccharification and fermentation assay were determined by Fourier transform infrared spectroscopy (FT-IR) using a Jasco infrared spectrometer (FT-IR-4100) equipped with a diamond-composite attenuated total reflectance (ATR) cell. The FT-IR spectrum was obtained operating with a resolution of $4 \mathrm{~cm}^{-1}, 16$ scans, and frequency range of $4000-600 \mathrm{~cm}^{-1}$. The FI-TR bands were identified for comparison with those reported in the literature (Santos et al., 2015; Dávila et al., 2017). 


\section{Results and discussion}

\subsection{Raw material}

Chemical composition of vine pruning residue (expressed in $g$ per $100 \mathrm{~g}$ VPR on oven-dry basis \pm standard deviation based in three replicate determinations) was as follows: $32.9 \pm 0.66$ of cellulose (as glucan); $14.87 \pm 0.17$ of xylan; $0.40 \pm 0.06$ of arabinan; $3.95 \pm 0.52$ of acetyl groups; $29.5 \pm 1.21$ of Klason lignin; $13.7 \pm 1.02$ of extractives in water; $2.94 \pm 0.89$ of extractives in ethanol and $3.32 \pm 0.56$ of ashes. Structural components of VPR (cellulose, Klason lignin and hemicellulose) represented $81.6 \%$ of the raw material. Extractives in water were analyzed by HPLC for determination of glucose concentration which represented $1.20 \%$ of raw material oven-dry basis. VPR was composed mainly of cellulose followed by lignin. Hemicellulose fraction was mainly composed of xylan which represented $77.4 \%$ of total identified hemicellulose compounds. Chemical composition was similar to the one reported by other authors for vine shoots (Rivas et al., 2007; Dávila et al., 2016).

\subsection{Process configuration}

Process configuration of this work was shown in Fig. 1. First, autohydrolysis stage was proposed in order to solubilize hemicellulose fraction into added value compounds such as oligosaccharides, recognized prebiotic functional food (Patel and Prajapati, 2015), and phenolic compounds, valued by their bioactive properties and antioxidant activity (Rivas et al., 2013). Autohydrolyzed VPR from the first stage was assayed for enzymatic saccharification. After this evaluation, second autohydrolysis stage was proposed in order to improve the enzymatic susceptibility of cellulose. Finally, pretreated VPR from sequential stages of autohydrolysis was subjected to saccharification and fermentation for ethanol production. A systematic evaluation of operational conditions on fractionation of VPR was carried out as shown below.

\subsection{First stage of autohydrolysis pretreatment of vine pruning residue}

\subsubsection{Fractionation of vine pruning residue}

After the first stage of autocytolysis treatment, pretreated biomass and autohydrolysis liquor were analyzed to evaluate the degree of fractionation achieved. Table 1 showed the operational conditions of autohydrolysis treatment (temperature and time and its corresponding severity, $S_{0}$ ) and the results obtained. As observed in Table 1, solid yield (SY) decreased with the increase of severity. Glucan content varied in the range of 36.3-45.6 $\mathrm{g}$ of glucan per $100 \mathrm{~g}$ of autohydrolyzed VPR. The glucan recovery was $77.2-95.2 \%$ with respect to glucan content in raw material at $S_{0}=4.90$ and 3.36, respectively (boundary conditions evaluated in this work). The lowest glucan recovery at $S_{0}=4.90$ revealed high cellulose loss, that is an undesirable condition for vine pruning processing from a biorefinery approach. Buratti and coworkers (2015) reported a $69.1 \%$ of cellulose recovery from steam exploded residue from vineyard at $S_{0}=4.24$. The wide range of severities studied in this work displayed the behavior of the raw material to selective fractionation of autohydrolysis treatment. As observed from data listed in Table 1, xylan solubilization increased with the severity of treatment achieving up to $93 \%$ of xylan solubilization at $S_{0}=4.90$. Lignin content ranged from 30.60 to $45.66 \mathrm{~g}$ of lignin per $100 \mathrm{~g}$ of autohydrolyzed VPR which corresponded to 90 and $100 \%$ of recovery, respectively. Similar range of severities were evaluated for fractionation of agricultural residues as barley straw (Vargas et al., 2015), rice straw (Moniz et al., 2015) or olive tree pruning (Silva-
Fernandes et al., 2015) in which cellulose recovery of $90 \%$ were obtained at values of $S_{0}$ in the range of 3.15-4.36.

Table 1 also provides the chemical composition of liquors from first autohydrolysis step. As expected, xylooligosaccharides were the main component at milder conditions of treatment $\left(S_{0}=3.83-4.26\right)$. As severity increases, the hydrolysis of oligosaccharides into monosaccharides is more effective but after a critical value leads to the subsequent dehydration of sugars in furfural and HMF. This behavior is typical of the severity rise effect on autohydrolysis treatment of lignocellulosic materials (Garrote et al., 2002; Ruiz et al., 2013). A 16-50\% of xylan solubilization into xylooligosaccharides was obtained at $S_{0} 3.36-3.80$, achieving a maximal extraction of xylan as xylooligomers $(65.1 \%)$ at $S_{0}=4.13$. The lowest recovery of xylan as xylooligosaccharides $(4.4 \%)$ was obtained at the highest severity factor evaluated $\left(S_{0}=4.90\right)$. The maximal concentration (measured as sum) of xylooligosaccharides and xylose (13.19 and $2.01 \mathrm{~g} / \mathrm{L}$, respectively) were also obtained at $S_{0}=4.13$ which corresponded to $75.9 \%$ recovery of xylan in the raw material. Similar concentration of xylooligosaccharides $(12.2 \mathrm{~g} / \mathrm{L})$ or xylose $(14.8 \mathrm{~g} / \mathrm{L})$ were obtained by autohydrolysis treatment using trimming vine shoots at $S_{0}=4.01$ (Dávila et al., 2016) and by sequential stages of autohydrolysis at $S_{0}=4.08$ and acid hydrolysis with $1 \% \mathrm{H}_{2} \mathrm{SO}_{4}(\mathrm{w} / \mathrm{w}$ ) (Moldes et al., 2007), respectively. The concentration of glucooligosaccharides and acetyl groups linked to oligosaccharides achieved an average value of $5.24 \mathrm{~g} / \mathrm{L} \pm 0.39$ and $2.05 \mathrm{~g} / \mathrm{L} \pm 0.67$, respectively. Regarding degradation compounds, furfural and HMF concentrations were higher than $1 \mathrm{~g} / \mathrm{L}$ at $S_{0}=4.42$ and 4.72 , respectively. On the other hand, acetic acid from deacetylation of hemicellulose had a significant increase up to $3.86 \mathrm{~g} / \mathrm{L}$ at $S_{0}=4.90$.

Taking into account that by-products from wine-making are enriched in phenolic compounds with valuable antioxidant properties to be used in food, pharmaceutical and cosmetic industries (Delgado-Torre et al., 2012; Teixeira et al., 2014), total phenolic compounds in autohydrolysis liquor were also quantified and included in Table 1. Phenolic compounds obtained by autohydrolysis achieved an average value of $1.5 \mathrm{~g} / \mathrm{L} \pm 0.39$, achieving a maximal concentration of 2.09 of GAE g/L (or $1.88 \mathrm{~g}$ GAE per $100 \mathrm{~g}$ of VPR) at $S_{0}=4.13$. Autohydrolysis treatment has been employed for extraction of phenolic compounds, obtaining approximately 2 GAE g per $100 \mathrm{~g}$ from lignocellulosic wastes such as corncobs, eucalyptus wood and grape pomace at high temperatures $\left(240{ }^{\circ} \mathrm{C}\right)$ in non-isothermal regime (Conde et al., 2011). Traditionally, extraction methods for phenolic compounds recovery from vine by-products use toxic solvents such as methanol (Delgado-Torre et al., 2012). Water extraction at high temperatures is an environmentally-friendly alternative to traditional extraction methods.

\subsubsection{Enzymatic susceptibility of vine pruning residue}

For a global evaluation of pretreatment, the enzymatic susceptibility of pretreated biomass was also studied. Effect of autohydrolysis pretreatment on time course of enzymatic saccharification was represented in Fig. 2 (assays were carried out in duplicate with a calculated relative error $\leq 10 \%$ ). At $S_{0}=4.05-4.42$, glucan to glucose conversion (GGC) at $72 \mathrm{~h}$ of enzymatic hydrolysis achieved values of $73-78 \%$. Under these conditions of pretreatment, more than $60 \%$ of xylan was solubilized into xylooligosaccharides, disclosing a suitable range of conditions to attain a biorefinery scheme. The highest glucan conversion (91\%) was achieved at $S_{0}=4.90$ in which oligosaccharides and sugars were completely degraded in the liquid phase. Glucose yield higher than $90 \%$ was also obtained from alkaline pretreated residue from vineyard using $2.5 \% \mathrm{NaOH}$ at $100{ }^{\circ} \mathrm{C}$ for $30 \mathrm{~min}$ (Cotana et al., 2015). Enzymatic saccharification yield of steam exploded residue from vineyard 
a)

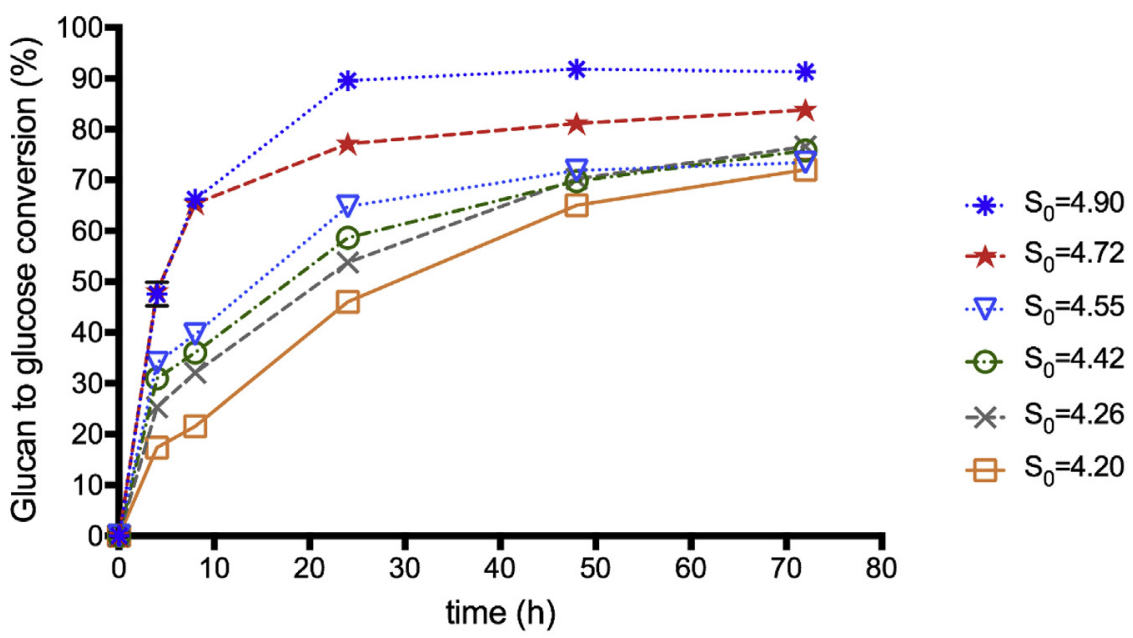

b)

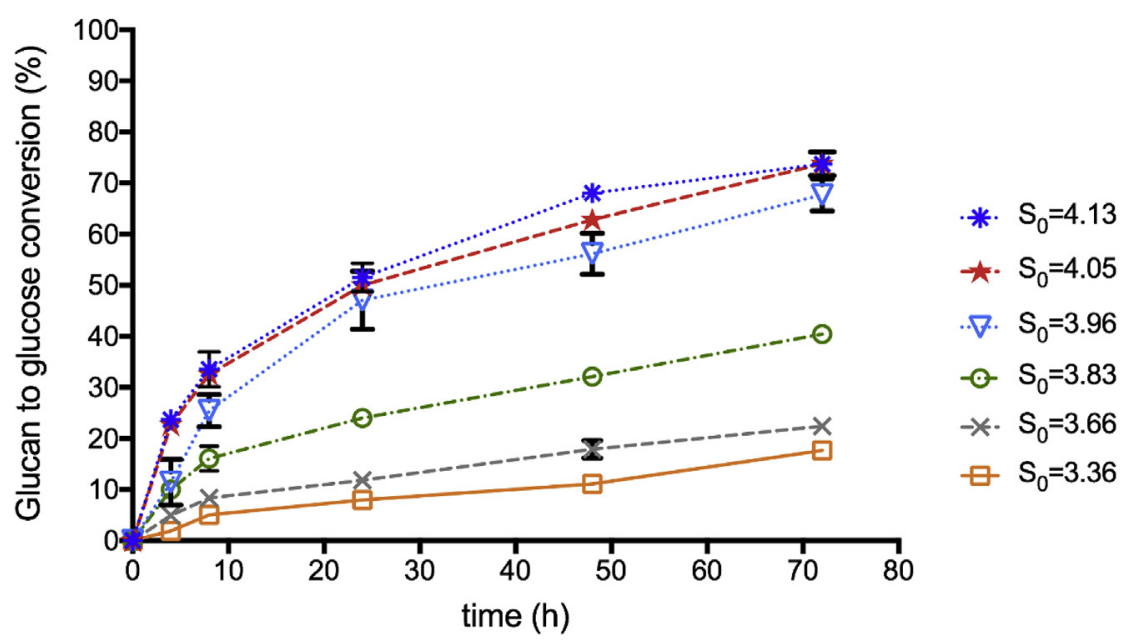

Fig. 2. Time course of cellulose to glucose conversion at $S_{0}$ in the range of 3.36-4.90.

attained $86 \%$ at $S_{0}=4.56$ (Buratti et al., 2015). Xylose was also generated in enzymatic hydrolysis assays at a concentration of $0.4-2.3 \mathrm{~g} / \mathrm{L}$, corresponding to a xylan conversion of $12-100 \%$, respectively. In this work, the increment in the severity factor significantly enhanced the enzymatic susceptibility of cellulose with 5.4-fold higher conversion comparing to the lowest severity $\left(S_{0}=3.36\right)$.

Considering the autohydrolysis liquor composition in xylooligosaccharides (13.19 $\mathrm{g} / \mathrm{L})$ and enzymatic susceptibility of solid phase (glucan to glucose conversion of $73.7 \%$ ), operational condition of $S_{0}=4.13$ was selected to advance on further fractionation of VPR. For that, an additional treatment was carried out reducing the LSR up to $6 \mathrm{~g}$ per $\mathrm{g}$ with the objective of reducing water consumption in the treatment and increase the concentration of hemicellulose-derived compounds in autohydrolysis liquor. The solid and liquid phase composition was shown in Table 2. As seen, oligosaccharides concentration was considerably increased up to $31.2 \mathrm{~g} / \mathrm{L}$ (17.2 $\mathrm{g} / \mathrm{L}$ as xylooligosaccharides).

Some of the phenolic compounds present in the autohydrolysis liquor were identified by UHPLC. Phenolic acids from wine byproduct include benzoic and cinnamic acid derivatives, being hydroxycinnamic acid the most abundant in these residues (Teixeira et al., 2014). In accordance, hydroxycinnamic acids were the ones found in the highest percentage in the autohydrolysis liquor (caffeic acid, p-coumaric acid, chlorogenic acid, rosmarinic acid and ferulic acid) (Table 3). Moreover, hydroxybenzoic acids such as vanillic, gallic and syringic acid were also identified. Grape stems constitute an enriched source of flavonoids and stilbenes (containing resveratrol in high concentration) (Anastasiadi et al., 2012). More recently, shoots, leaves and tendrils from six grapevine varieties were analyzed for their content in resveratrol in which $9.25-12.5 \mathrm{mg}$ of trans-resveratrol per $\mathrm{kg}$ of shoots from St. Laurent vine variety was reported using an extraction method with methanol: ethyl acetate (Lachman et al., 2016). In this study, the extraction of resveratrol from VPR by autohydrolysis achieved a concentration of $12.46 \mathrm{mg} / \mathrm{L}$ (or $79 \mathrm{mg}$ per $\mathrm{kg}$ of VPR).

Antioxidant activity of autohydrolysis liquor was also reported in Table 3 showing antioxidant capacity expressed as Trolox equivalent. Antioxidant activity of phenolic compounds obtained by autohydrolysis treatments, liquid hot water and steam explosion, of olive pruning was reported to be 7.33 and $6.31 \mathrm{mmol}$ DPPH per $100 \mathrm{~g}$ of extract, respectively (Conde et al., 2009). Recently, antioxidant, antifeedant and phytotoxic activities of aqueous extracts from vine-shoots have been reported showing the potential of this residue to be applied in cosmetics, nutraceuticals or pharmaceuticals (Sánchez-Gómez et al., 2017). Values $I C_{50}$ for extract samples from vine shoots of $32 \mu \mathrm{g} / \mathrm{mL}$ and $38 \mu \mathrm{g} / \mathrm{mL}$ were reported using conventional solid-liquid extraction and microwave 
Table 3

Antioxidant activity and phenolic compounds composition in liquors from first stage $\left(S_{0}=4.13\right)$ and second stage $\left(S_{0}=4.60\right)$ of autohydrolysis.

\begin{tabular}{lll}
\hline Severity Factor $\left(\mathrm{S}_{0}\right)$ & 4.13 & 4.60 \\
\hline Antioxidant activity & & \\
\hline ABTS (mg per L Trolox equivalent) & $247.05 \pm 0.34$ & $35.56 \pm 0.03$ \\
DPPH (mg per L Trolox equivalent) & $173.45 \pm 0.03$ & $45.2 \pm 0.21$ \\
ABTS IC 50 (mg of autohydrolysis liquor per $\mathrm{mL})$ & $10.97 \pm 0.32$ & $50.2 \pm 0.15$ \\
DPPH IC 50 (mg of autohydrolysis liquor per $\mathrm{mL})$ & $9.89 \pm 0.58$ & $57.25 \pm 0.25$ \\
\hline Total phenol (GAE g/L) & $2.35 \pm 0.02$ & $1.43 \pm 0.06$ \\
\hline Phenolic Compound & $(\mathrm{mg} / \mathrm{L})$ & $(\mathrm{mg} / \mathrm{L})$ \\
\hline catechin & 47.54 & 14.86 \\
syringic acid & 18.88 & 12.65 \\
chlorogenic acid & 34.70 & 0.0 \\
caffeic acid & 33.60 & 0.0 \\
vanillic acid & 21.96 & 16.57 \\
ferulic acid & 5.0 & 0.0 \\
gallic acid & 8.39 & 5.06 \\
p-coumaric acid epicatechin & 5.54 & 4.60 \\
o-coumaric acid & 10.32 & 4.72 \\
hesperidin & 21.84 & 0.0 \\
cinnamic acid & 7.26 & 6.91 \\
resveratrol & 12.46 & 11.78 \\
rutin & 20.62 & 10.40 \\
rosmarinic acid & 12.24 & 11.72 \\
\hline
\end{tabular}

extraction, respectively (Sánchez-Gómez et al., 2017).

\subsection{Second stage of autohydrolysis pretreatment of vine pruning residue}

\subsubsection{Effect on solid and liquid composition}

Sequential second stage of autohydrolysis was studied for the improvement of enzymatic cellulose susceptibility. VPR from autohydrolysis treatment at $S_{0}=4.13$ and LSR of $6 \mathrm{~g}$ per $\mathrm{g}$ was employed as feedstock in a second autohydrolysis step in the range of temperatures from 180 to $200{ }^{\circ} \mathrm{C}$ for $30-60 \mathrm{~min}$, corresponding to total $S_{0}=4.36-4.69$ (including the severity from the first stage of autohydrolysis). Table 2 collected solid and liquid composition from autohydrolysis in two sequential stages. Under the evaluated conditions of treatment, high glucan recovery was obtained (94.0-96.6 $\mathrm{g}$ of glucan per $100 \mathrm{~g}$ of glucan in first autohydrolyzed VPR). Glucan content increased with the severity factor achieving $41.7 \mathrm{~g}$ of glucan per $100 \mathrm{~g}$ of second autohydrolyzed VPR at $S_{0}=4.60$. These results were comparable with glucan obtained from first autohydrolysis stage for $S_{0}$ of 4.55 and 4.72 (Table 1). Xylan recovery was in the range of $67.5-41.4 \mathrm{~g}$ of xylan per 100 of xylan in first autohydrolyzed VPR for the boundary conditions $\left(S_{0}\right.$ : 4.36 and 4.69 , respectively). On the other hand, lignin recovery remained almost constant with an average value of $90.56 \pm 0.96 \mathrm{~g}$ of lignin per $100 \mathrm{~g}$ of lignin in the first autohydrolyzed solid. Consequently, the main compound in the liquid phase (or liquor from second autohydrolysis) were xylooligosaccharides which achieved a maximum concentration $(6.88 \mathrm{~g} / \mathrm{L})$ at $S_{0}=4.60$. Considering the xylooligosaccharides extraction in the first autohydrolysis stage, $81.2 \%$ of xylan was recovered as xylooligosaccharides from first and second autohydrolysis stages (73.4 and $18.4 \%$ at $S_{0}=4.13$ and $S_{0}=4.60$, respectively). Moreover, phenolic compounds present in the liquor from second autohydrolysis were also analyzed by UHPLC and included in Table 3. The concentration of identified phenolic compounds in the second step of autohydrolysis was reduced. Nevertheless, the antioxidant activity was similar probably caused by the higher concentration of HMF ( $3.8 \mathrm{~g}$ / L) formed due to the harder conditions of the second autohydrolysis.

\subsubsection{Effect on enzymatic susceptibility of vine pruning residue}

Regarding enzymatic hydrolysis from the second stage of autohydrolysis, Table 4 showed operational conditions evaluated and the main results obtained at $72 \mathrm{~h}$ of hydrolysis. The percentage of solids was increased from $4 \%$ up to $10 \%$ in order to increase glucose concentration and consequently ethanol in subsequent fermentation assays. Glucan to glucose conversion was significantly increased, achieving 99\% of conversion at the highest severity $\left(S_{0}=4.69\right)$. The maximal concentration of glucose $(45.4 \mathrm{~g} / \mathrm{L})$ was obtained at $S_{0}=4.69$ and $10 \%$ of solids. The increase of solid loading up to $10 \%$ reduced the glucan to glucose conversion between 1.6-4.6\% achieving a glucose concentration 2.2-fold higher than the concentration obtained when operating at $4 \%$ of solids. Glucan conversion from $S_{0}=4.60$ was higher than $80 \%$. In comparison with the saccharification of first autohydrolysis stage $\left(S_{0}=4.13\right)$, an increase of $35.6 \%$ of enzymatic hydrolysis conversion was obtained at $S_{0}=4.69$ and $4 \%$ of solids. On the other hand, $43.7 \%$ augment in glucose conversion was achieved using $10 \%$ of solid loading and severity of $S_{0}=4.69$.

The improvement of enzymatic hydrolysis after autohydrolysis in two sequential stages can be due to structural changes. Scanning Electronic Micrographs (SEM) of raw material and pretreated samples were taken (see Fig. 3). These treated samples correspond to treatment at $180{ }^{\circ} \mathrm{C}$ for $60 \mathrm{~min}$ (first autohydrolysis, $S_{0}=4.13$ ) and $200{ }^{\circ} \mathrm{C}$ for $30 \mathrm{~min}$ (second autohydrolysis, Total $S_{0}=4.60$ ). Clear differences between native and pretreated biomasses were shown. The raw material displayed an ordered structure of fibers. On the other hand, pretreated sample from the first autohydrolysis showed a more porous structure and the sample from autohydrolysis in two sequential stages presented a more defragmented and open structure.

Few works have reported the effect of autohydrolysis in two stages on lignocellulosic biomass being the results obtained in this work favorably compared with the literature (Park et al., 2016; Guilliams et al., 2016). Recently, this strategy has been employed to reduce the inhibitor loading in wheat straw and hardwoods hydrolysates (Min et al., 2015; Park et al., 2016). It was also employed for the improvement of enzymatic cellulose saccharification, an increase from 67 to $75 \%$ of glucose yield with 30 FPU per $g$ was obtained by two steps of autohydrolysis using coastal Bermuda grass (Lee et al., 2010). On the other hand, combined autohydrolysis treatment at $S_{0}=4.66$ achieved a $66 \%$ of sugar recovery from wheat straw (Min et al., 2015).

\subsection{Bioethanol production by separate and simultaneous saccharification and fermentation}

Taking into account the results discussed in the above section, VPR treated by autohydrolysis in two sequential stages (Total $S_{0}=4.60$ ) was chosen for ethanol production. At this condition, $96 \%$ of glucan was recovered after treatment, xylooligosaccharides in autohydrolysis liquor achieved the highest concentration $(6.9 \mathrm{~g} / \mathrm{L})$ and enzymatic saccharification conversion was higher than $80 \%$. For ethanol production, two strategies were evaluated: separated hydrolysis and fermentation (SHF) and simultaneous saccharification and fermentation (SSF). Operational conditions for SHF and SSF were included in Table 5. SHF experiments were shown in Fig. 4a (assays were carried out in duplicate with a calculated relative error $\leq 10 \%$ ). Glucose concentration achieved the maximal concentration of 47.2 and $16.5 \mathrm{~g} / \mathrm{L}$ for 10 and $4 \%$ of solids, respectively. After $48 \mathrm{~h}$ of enzymatic hydrolysis, yeast cells were added achieving maximal ethanol concentration within 4 and $8 \mathrm{~h}$ of fermentation with an ethanol yield $>90 \%$.

SSF has been proposed as a strategy for improvement of ethanol yield since glucose is simultaneously produced and consumed 
Table 4

Enzymatic hydrolysis conditions and main results obtained from saccharification of second autohydrolysis stage at $72 \mathrm{~h}$.

\begin{tabular}{|c|c|c|c|c|c|c|c|c|c|}
\hline \multirow[t]{2}{*}{ run } & \multicolumn{4}{|c|}{ Operational conditions } & \multicolumn{5}{|l|}{ Main Results } \\
\hline & Temperature $\left({ }^{\circ} \mathrm{C}\right)$ & Time (min) & $\begin{array}{l}\text { Severity }\left(S_{0}\right) \text { or Total } \\
\left.\text { Severity (Total } S_{0}^{\text {a }}\right)\end{array}$ & $\begin{array}{l}\text { Solid } \\
\text { loading (\%) }\end{array}$ & $\begin{array}{l}\text { Enzyme to Substrate } \\
\text { Ratio (ESR, FPU per g) }\end{array}$ & $\begin{array}{l}\text { Glucose at } \\
72 \mathrm{~h}(\mathrm{~g} / \mathrm{L})\end{array}$ & $\begin{array}{l}\text { Xylose at } \\
72 \mathrm{~h}(\mathrm{~g} / \mathrm{L})\end{array}$ & $\begin{array}{l}\text { Glucan to glucose } \\
\text { Conversion (\%) }\end{array}$ & $\begin{array}{l}\text { Xylan to glucose } \\
\text { Conversion (\%) }\end{array}$ \\
\hline 1 & 180 & 60 & 4.13 & 4 & 25 & $13.20 \pm 0.01$ & $3.51 \pm 0.30$ & $73.21 \pm 0.06$ & $77.5 \pm 0.74$ \\
\hline 2 & & & & 10 & 25 & $29.85 \pm 0.34$ & $8.21 \pm 0.12$ & $68.45 \pm 0.78$ & $72.5 \pm 2.99$ \\
\hline 3 & 180 & 40 & $4.36^{\mathrm{a}}$ & 4 & 25 & $12.80 \pm 0.28$ & $3.05 \pm 0.10$ & $72.63 \pm 1.60$ & $96.1 \pm 2.56$ \\
\hline 4 & & & & 10 & 25 & $27.55 \pm 0.07$ & $7.80 \pm 0.05$ & $70.84 \pm 3.18$ & $98.3 \pm 1.28$ \\
\hline 5 & 180 & 60 & $4.46^{\mathrm{a}}$ & 4 & 25 & $13.47 \pm 0.13$ & $2.88 \pm 0.25$ & $74.69 \pm 0.75$ & $96.3 \pm 6.40$ \\
\hline 6 & & & & 10 & 25 & $34.95 \pm 2.89$ & $7.20 \pm 0.20$ & $71.25 \pm 6.65$ & $96.3 \pm 0.43$ \\
\hline 7 & 200 & 30 & $4.60^{\mathrm{a}}$ & 4 & 25 & $15.50 \pm 0.14$ & $2.80 \pm 0.10$ & $85.16 \pm 0.91$ & $97.9 \pm 2.56$ \\
\hline 8 & & & & 10 & 25 & $40.50 \pm 1.55$ & $7.05 \pm 0.34$ & $83.21 \pm 3.53$ & $98.6 \pm 0.78$ \\
\hline 9 & 200 & 40 & $4.69^{\mathrm{a}}$ & 4 & 25 & $17.48 \pm 0.74$ & $1.91 \pm 0.30$ & $99.30 \pm 4.21$ & $98.2 \pm 7.69$ \\
\hline 10 & & & & 10 & 25 & $45.43 \pm 0.03$ & $4.80 \pm 2.86$ & $97.70 \pm 0.08$ & $98.7 \pm 5.98$ \\
\hline
\end{tabular}

a Total $S_{0}$ was calculated taking into account the severity of first stage and second.
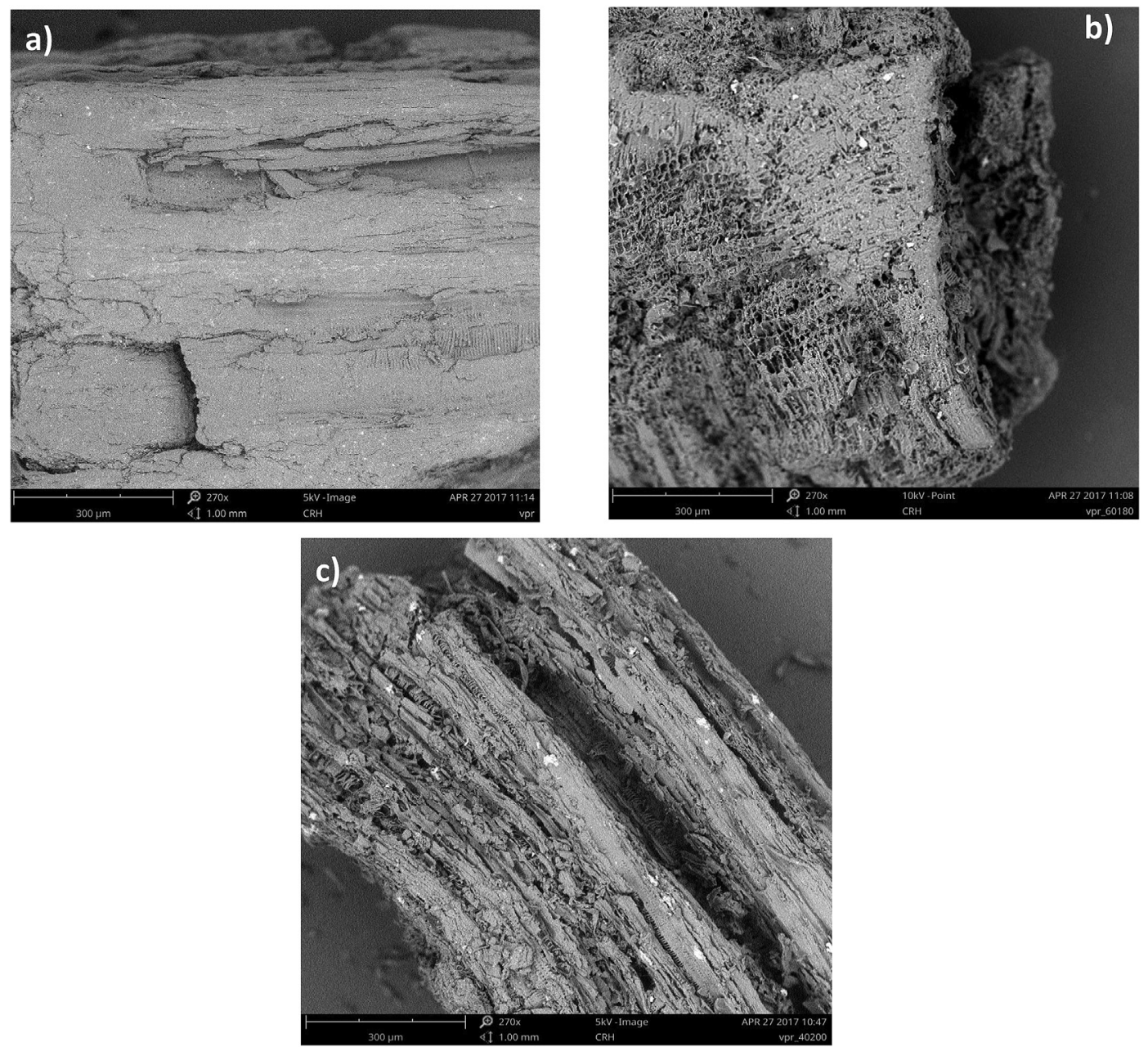

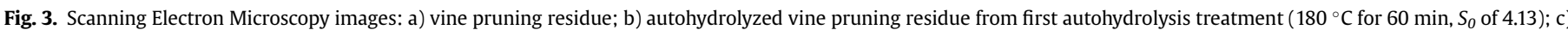
autohydrolyzed vine pruning residue from sequential stages of autohydrolysis ( $200{ }^{\circ} \mathrm{C}$ for $40 \mathrm{~min}$, Total $S_{0}$ of 4.60 ).

avoiding end-product inhibition of cellulose enzymes (LópezLinares et al., 2014). In this sense, solid loading was increased up to $16.7 \%$ and enzyme loading was decreased (15 FPU per g) to evaluate the SSF strategy under demanding conditions. Ethanol profiles of SSF experiments were shown in Fig. 4b (assays were carried out in duplicate with a calculated relative error $\leq 10 \%$ ). Ethanol production was affected by a reduction of enzyme loading achieving low ethanol yields $\left(\mathrm{Y}_{\mathrm{Et}}=52.9 \%\right.$ ) (Table 5). Ethanol concentration of $30 \mathrm{~g} / \mathrm{L}$ corresponding to an $\mathrm{Y}_{\mathrm{Et}}$ of $83 \%$ was obtained with enzyme loading of 25 FPU per g. Ethanol production was strongly affected by the enzyme loading. Nevertheless, recent studies on enzyme recycling suggested the possibility of enzyme recovery being used in sequential batches reducing the overall enzyme loading (Gomes et al., 2016).

Ethanol results obtained in this work can be compared with reported data using residues from wine-making process. SHF 
Table 5

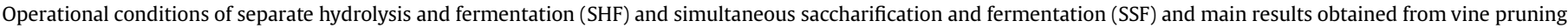
residue from sequential stages of autohydrolysis (Total $S_{0}=4.60$ ).

\begin{tabular}{|c|c|c|c|c|}
\hline \multirow[t]{2}{*}{ Run } & \multicolumn{2}{|c|}{ Operational conditions } & \multicolumn{2}{|l|}{ Main results } \\
\hline & Solid loading (\%) & Enzyme Substrate Ratio (FPU per g) & Ethanol max $(\mathrm{g} / \mathrm{L})$ & Ethanol yield, $\mathrm{Y}_{\mathrm{Et}}(\%)$ \\
\hline SHF1 & 4 & 25 & $8.84 \pm 0.08$ & $95.26 \pm 086$ \\
\hline SHF2 & 10 & 25 & $20.97 \pm 0.21$ & $93.50 \pm 1.07$ \\
\hline SSF1 & 16.7 & 25 & $30.08 \pm 0.85$ & $83.41 \pm 2.36$ \\
\hline SSF2 & 16.7 & 15 & $19.09 \pm 0.33$ & $52.94 \pm 0.92$ \\
\hline
\end{tabular}
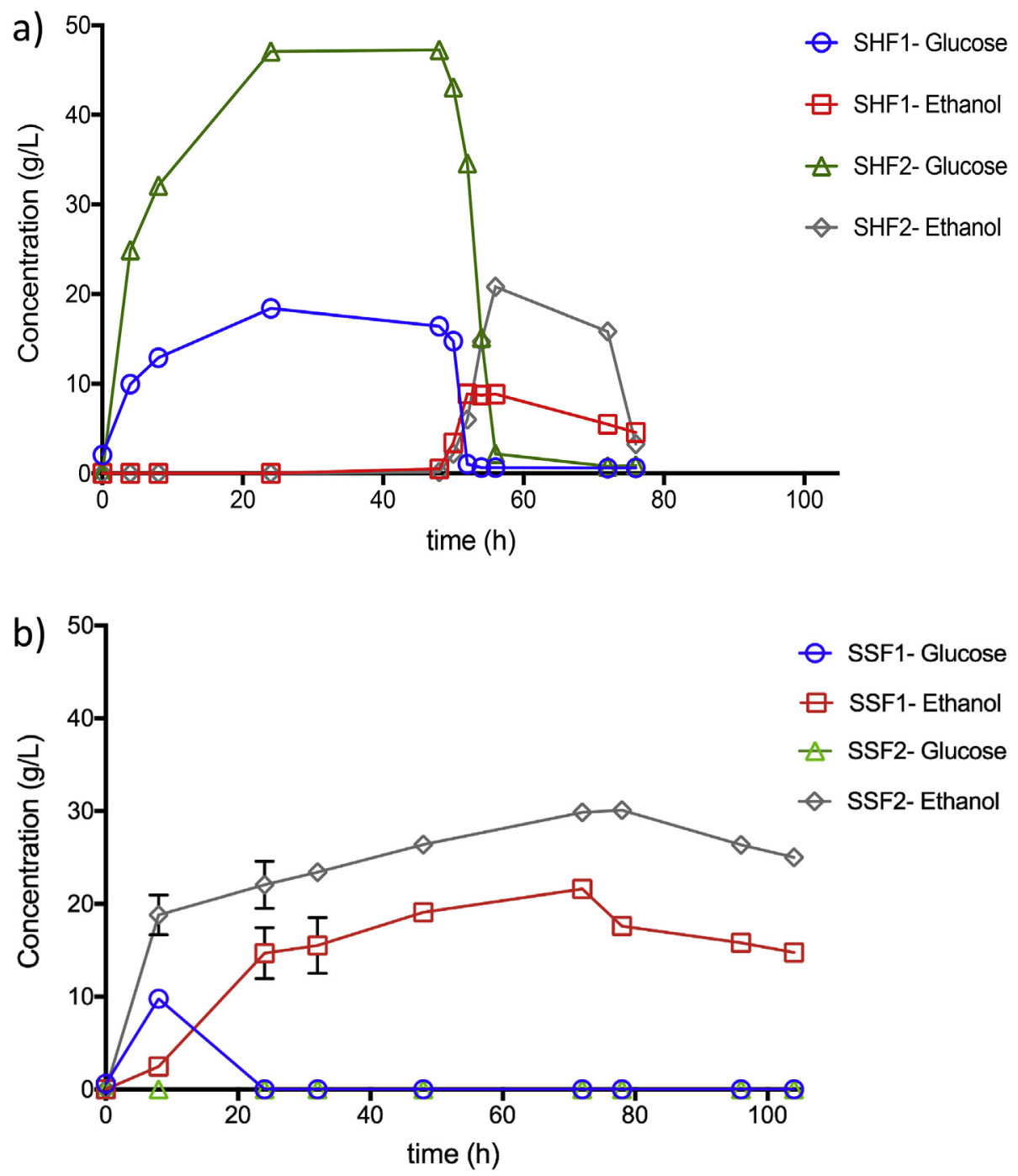

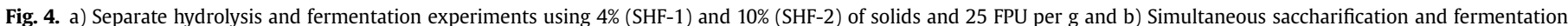
(SSF) using $16.7 \%$ of solids and 25 (SSF-1) and 25 FPU per g (SSF-2).

strategy was also used for ethanol production from residue derived from vineyard pruning treated by steam explosion $\left(S_{0}=4.56\right)$, obtaining $8.8 \mathrm{~g} / \mathrm{L}$ of ethanol with $81.09 \%$ of ethanol yield (Buratti et al., 2015). By-products from wine-making processing such as grape skins (containing water-soluble carbohydrates) have been used as raw material for ethanol production obtaining a maximal concentration of ethanol $(22 \mathrm{~g} / \mathrm{L})$ with ethanol yield of $0.51 \mathrm{~g}$ per $\mathrm{g}$ using sequential treatments of hexane and water extraction and acid hydrolysis (Mendes et al., 2013). Pretreated grape stalks by autohydrolysis followed by acid hydrolysis were also used for ethanol production obtaining $20.84 \mathrm{~g} / \mathrm{L}$ (0.35 g ethanol per $\mathrm{g}$ sugars) (Egüés et al., 2013).

3.6. Recovered spent residue after saccharification and fermentation process

Finally, spent solid residue was recovered after SHF (using 4\% solids) and analyzed for chemical composition. Results showed a solid residue mainly composed by lignin ( $80.7 \mathrm{~g}$ of Klason lignin per $100 \mathrm{~g}$ of spent solid from SHF). This result can be compared to Klason lignin from isolated lignins (81-86\%) obtained by autohydrolysis followed by organosolv, acetosolv and alkali processes 
(Dávila et al., 2017). The chemical structure of the recovered residue was analyzed by FT-IR (Fig. 5a). The FT-IR analysis is used to determine the presence of functional groups, lignin purity and lignin units composition (Santos et al., 2015). The spectrum showed the characteristic bands for lignin functional groups: hydroxyl group and phenol compounds between 3500 and $3000 \mathrm{~cm}^{-1}$, aromatic ring in the region of $1500 \mathrm{~cm}^{-1}$, carbonyl and carboxyl groups in the band of $1700 \mathrm{~cm}^{-1}$. The FT-IR spectrum of spent residue from SHF also showed an intensity of monolignols present in the structure of lignin: signal assigned to syringyl units (the bands at 1330 and $833 \mathrm{~cm}^{-1}$ ) and guaiacyl units (the bands observed at 1511, 1421 and $913 \mathrm{~cm}^{-1}$ ). This spectrum can be compared with FT-IR spectra from isolated lignins obtained by sequential stages of autohydrolysis and organosolv, acetosolv and $8 \% \mathrm{NaOH}$ of vine shoot (Dávila et al., 2017).

On the other hand, thermogravimetric analysis (TGA) of this sample was also carried out (Fig. 5b), weight loss (4.7\%) at $100{ }^{\circ} \mathrm{C}$ was due to moisture removal. In the range of $100-280{ }^{\circ} \mathrm{C}$, the weight loss was almost constant (corresponding to 6\%). The highest weight loss (30\%) was achieved at $368{ }^{\circ} \mathrm{C}$, which was similar to those reported by previous workers using lignin extracted from enzymatic hydrolysis process (Tana et al., 2016). In the range of $420-900{ }^{\circ} \mathrm{C}$, the weight loss $(20 \%)$ was less pronounced. Final residue yield for spent solid recovered after SHF was 30\%, corresponding to ashes and protein contents (Tana et al., 2016). Moreover, residual yeast from fermentation process is also present in this kind of residues (Yunus et al., 2015). Therefore, the use of spent residue from saccharification and fermentation process as new protein and antioxidants source could be an interesting alternative leading to widened valorization of VPR.

\section{Conclusions}

In this work, autohydrolysis in two sequential stages was

a)
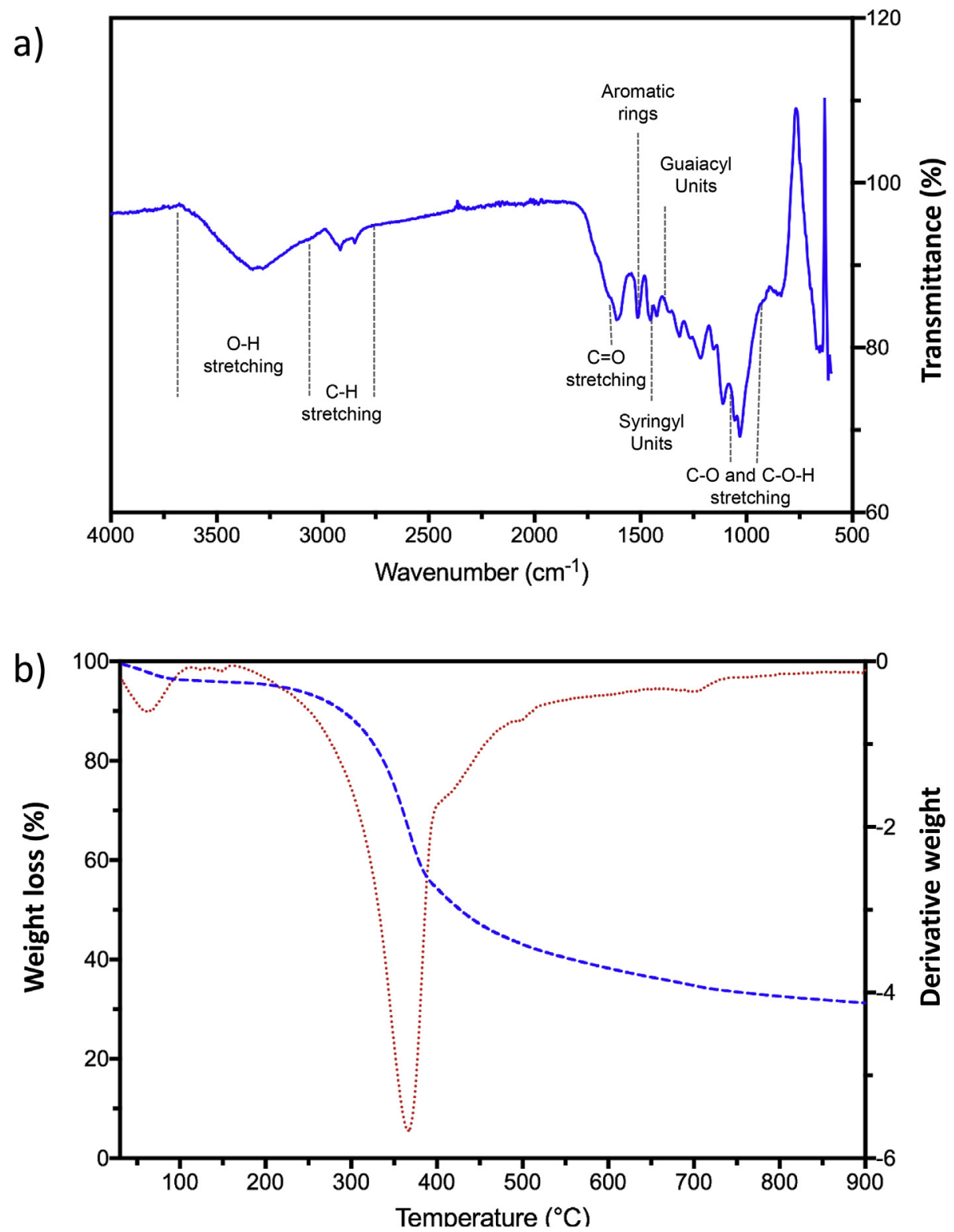

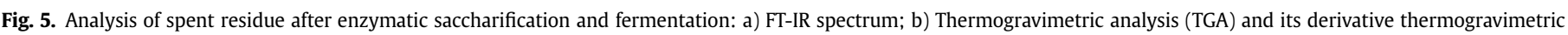
(DTG) curve. 
proposed for the integral valorization of VPR. High concentration of oligosaccharides with antioxidant activity was obtained from the first step of autohydrolysis. The second autohydrolysis improved the enzymatic saccharification of VPR. Selected conditions led to the following products yield (per $100 \mathrm{~kg}$ of VPR): $13.6 \mathrm{~kg}$ of xylooligosaccharides, $3.1 \mathrm{~kg}$ of phenolic compounds, $13.1 \mathrm{~kg}$ of ethanol and $27.0 \mathrm{~kg}$ of lignin in four separate streams. As a whole, $69 \mathrm{~kg}$ of value added compounds were obtained from processing of $100 \mathrm{~kg}$ VPR being suitable for manufacture in energy, pharmaceutical and food industries.

\section{Acknowledgements}

This study was supported by the Portuguese Foundation for Science and Technology (FCT) under the scope of the strategic funding of UID/BIO/04469/2013 unit and COMPETE 2020 (POCI-010145-FEDER-006684) and BioTecNorte operation (NORTE-01-0145FEDER-000004) funded by European Regional Development Fund under the scope of Norte2020 - Programa Operational Regional do Norte. Meirielly S Jesus thanks her fellowship (Ref. 202259/2014-5) supported by the International Cooperation Program CNPq/CSF at the University of Minho financed by CNPq-Brazilian Federal Agency. Aloia Romaní thanks financial support obtained by Deputación de Ourense (Ref. INOU 15-08).

\section{References}

Abatzoglou, N., Chornet, E., Belkacemi, K., Overend, R.P., 1992. Phenomenological kinetics of complex systems: the development of a generalized severity parameter and its application to lignocellulosics fractionation. Chem. Eng. Sci. 47 (5), 1109-1122.

Anastasiadi, M., Pratsinis, H., Kletsas, D., Skaltsounis, A.-L., Haroutounian, S.A., 2012 Grape stem extracts: polyphenolic content and assessment of their in vitro antioxidant properties. LWT-Food Sci. Technol. 48, 316-322.

Bailey, M.J., Biely, P., Poutanen, K., 1992. Interlaboratory testing of methods for assay of xylanase activity. J. Biotechnol. 23, 257-270.

Ballesteros, L.F., Cerqueira, M.A., Teixeira, J.A., Mussatto, S.I., 2015. Characterization of polysaccharides extracted from spent coffee grounds by alkali pretreatment. Carbohydr. Polym. 127, 347-354.

Brito, P.S.D., Oliveira, A.S., Rodrigues, L.F., 2014. Energy valorization of solid vines pruning by thermal gasification in a pilot plant. Waste Biomass Valor. 5, 181-187.

Buratti, C., Barbanera, M., Lascaro, E., 2015. Ethanol production from vineyard pruning residues with steam explosion pretreatment. Environ. Prog. Sustain. Energy 34, 802-809.

Chaturvedi, V., Verma, P., 2013. An overview of key pretreatment processes employed for bioconversion of lignocellulosic biomass into biofuels and value added products. 3 Biotech. 3, 415-431.

Conde, E., Cara, C., Moure, A., Ruiz, E., Castro, E., Domínguez, H., 2009. Antioxidant activity of the phenolic compounds released by hydrothermal treatments of olive tree pruning. Food Chem. 114, 806-812.

Conde, E., Moure, A., Domínguez, H., Parajó, J.C., 2011. Production of antioxidants by non-isothermal autohydrolysis of lignocellulosic wastes. LWT-Food Sci. Technol. 44, 436-442.

Cotana, F., Barbanera, M., Foschini, D., Lascaro, E., Buratti, C., 2015. Preliminary optimization of alkaline pretreatment for ethanol production from vineyard pruning. Energy Procedia 82, 389-394.

Dávila, I., Gordobil, O., Labidi, J., Gullón, P., 2016. Assessment of suitability of vine shoots for hemicellulosic oligosaccharides production through aqueous processing. Bioresour. Technol. 211, 636-644.

Dávila, I., Robles, E., Andrés, M.A., Gullón, P., 2017. Delignification alternatives of spent solid from autohydrolysis of vine shoots. Chem. Eng. Trans. 57, 85-90.

Delgado-Torre, P.M., Ferreiro-Vera, C., Priego-Capote, F., Pérez-Juan, P.M., Castro, M.D.L., 2012. Comparison of accelerated methods for the extraction of phenolic compounds from different vine-shoot cultivars. J. Agric. Food Chem. 60, 3051-3060.

Devesa-Rey, R., Díaz-Fierros, F., Barral, M.T., 2010. Trace metals in river bed sediments: an assessment of their partitioning and bioavailability by using multivariate exploratory analysis. J. Environ. Manage 91, 2471-2477.

Egüés, I., Sanchez, C., Mondragon, I., Labidi, J., 2012. Antioxidant activity of phenolic compounds obtained by autohydrolysis of corn residues. Ind. Crops Prod. 36, $164-171$.

Egüés, I., Serrano, L., Amendola, D., De Faveri, D.M., Spigno, G., Labidi, J., 2013. Fermentable sugars recovery from grape stalks for bioethanol production. Renew. Energy 60, 553-558.

Ferreira, S., Moreira, N.A., Monteiro, E., 2009. Bioenergy overview for Portugal.
Biomass Bioenergy 33, 1567-1576

Garrote, G., Domínguez, H., Parajó, J.C., 2002. Interpretation of deacetylation and hemicellulose hydrolysis during hydrothermal treatments on the basis of the severity factor. Process Biochem. 37, 1067-1073.

Ghose, T.K., 1987. International union of pure and applied chemistry applied chemistry division commission on biotechnology* Measurement of cellulase activities. Pure Appl. Chem. 59, 257-268.

Gomes, D., Domingues, L., Gama, M., 2016. Valorizing recycled paper sludge by a bioethanol production process with cellulase recycling. Bioresour. Technol. 216, 637-644.

González-Muñoz, M.J., Santos, V., Parajó, J.C., 2011. Purification of oligosaccharides obtained from Pinus pinaster hemicellulose by diafiltration. Desalin. Water Treat. 27, 48-53.

Guilliams, A., Pattathil, S., Willies, D., Richards, M., Pu, Y., Kandemkavil, S., Wiswall, E., 2016. Physical and chemical differences between one-stage and two-stage hydrothermal pretreated hardwood substrates for use in cellulosic ethanol production. Biotechnol. Biofuels 9, 30.

Gullón, P., Romaní, A., Vila, C., Garrote, G., Parajó, J.C., 2012. Potential of hydrothermal treatments in lignocellulose biorefineries. Biofuels, Bioprod. Biorefining 6, 219-232.

Jiménez, L., Rodríguez, A., Pérez, A., Moral, A., Serrano, L., 2008. Alternative raw materials and pulping process using clean technologies. Ind. Crops Prod. 28, $11-13$.

Hennig, C., Brosowski, A., Majer, S., 2016. Sustainable feedstock potential-a limitation for the bio-based economy? J. Clean. Prod. 123, 200-202.

Karacabey, E., Mazza, G., Bayındırlı, L., Artık, N., 2012. Extraction of bioactive compounds from milled grape canes (Vitis vinifera) using a pressurized lowpolarity water extractor. Food Bioprocess Technol. 5, 359-371.

Karlsson, H., Börjesson, P., Hansson, P.-A., Ahlgren, S., 2014. Ethanol production in biorefineries using lignocellulosic feedstock-GHG performance, energy balance and implications of life cycle calculation methodology. J. Clean. Prod. 83, 420-427.

Lachman, J., Kotíková, Z., Hejtmánková, A., Pivec, V., Pšeničnaja, O., Šulc, M., Střalková, R., Dědina, M., 2016. Resveratrol and piceid isomers concentrations in grapevine shoots, leaves, and tendrils. Hortic. Sci. 43, 25-32.

Lavoie, J.-M., Capek-Menard, E., Gauvin, H., Chornet, E., 2010. Production of pulp from Salix viminalis energy crops using the FIRSST process. Bioresour. Technol. 101, 4940-4946.

Lee, D.H., Cho, E.Y., Kim, C.J., Kim, S.B., 2010. Pretreatment of waste newspaper using ethylene glycol for bioethanol production. Biotechnol. Bioprocess Eng. 15, 1094-1101.

Lin, C.S.K., Koutinas, A.A., Stamatelatou, K., Mubofu, E.B., Matharu, A.S., Kopsahelis, N., Pfaltzgraff, L.A., Clark, J.H., Papanikolaou, S., Kwan, T.H., Luque, R., 2014. Current and future trends in food waste valorization for the production of chemicals, materials and fuels: a global perspective. Biofuels, Bioprod. Biorefining $8,686-715$.

López-Linares, J.C., Romero, I., Cara, C., Ruiz, E., Moya, M., Castro, E., 2014. Bioethanol production from rapeseed straw at high solids loading with different process configurations. Fuel 122, 112-118.

Max, B., Salgado, J.M., Cortês, S., Domínguez, J.M., 2010. Extraction of phenolic acids by alkaline hydrolysis from the solid residue obtained after pre hydrolysis of trimming vine shoots. J. Agric. Food Chem. 58, 1909-1917.

Mendes, J.A.S., Xavier, A.M.R.B., Evtuguin, D.V., Lopes, L.P.C., 2013. Integrated utilization of grape skins from white grape pomaces. Ind. Crops Prod. 49, 286-291.

Min, D., Xu, R., Hou, Z., Lv, J., Huang, C., Jin, Y., Yong, Q., 2015. Minimizing inhibitors during pretreatment while maximizing sugar production in enzymatic hydrolysis through a two-stage hydrothermal pretreatment. Cellulose 22, 1253-1261.

Moldes, A.B., Bustos, G., Torrado, A., Domínguez, J.M., 2007. Comparison between different hydrolysis processes of vine-trimming waste to obtain hemicellulosic sugars for further lactic acid conversion. Appl. Biochem. Biotechnol. 143, 244-256.

Moniz, P., Lino, J., Duarte, L.C., Roseiro, L.B., Boeriu, C.G., Pereira, H., Carvalheiro, F., 2015. Fractionation of hemicelluloses and lignin from rice straw by combining autohydrolysis and optimised mild organosolv delignification. BioResources 10, 2626-2641.

Overend, R.P., Chornet, E., 1987. Fractionation of lignocellulosics by steam-aqueous pretreatments. Phil. Trans. R. Soc. Lond. A 321, 523-536.

Park, J., Jones, B., Koo, B., Chen, X., Tucker, M., Yu, J.-H., Pschorn, T., Venditti, R. Park, S., 2016. Use of mechanical refining to improve the production of low-cost sugars from lignocellulosic biomass. Bioresour. Technol. 199, 59-67.

Patel, A., Prajapati, J.B., 2015. Biological Properties of Xylooligosaccharides as an Emerging Prebiotic and Future Perspective Biological Properties of Xylooligosaccharides as an Emerging Prebiotic and Future Perspective, vol. 9, pp. 28-36.

Peleteiro, S., Garrote, G., Santos, V., Parajó, J.C., 2014. Furan manufacture from softwood hemicelluloses by aqueous fractionation and further reaction in a catalyzed ionic liquid: a biorefinery approach. J. Clean. Prod. 76, 200-203.

Pereira, F.B., Romaní, A., Ruiz, H.A., Teixeira, J.A., Domingues, L., 2014. Industrial robust yeast isolates with great potential for fermentation of lignocellulosic biomass. Bioresour. Technol. 161, 192-199.

Pérez-Rodríguez, N., García-Bernet, D., Domínguez, J.M., 2016. Effects of enzymatic hydrolysis and ultrasounds pretreatments on corn cob and vine trimming shoots for biogas production. Bioresour. Technol. 221, 130-138.

Rivas, B., Torrado, A., Rivas, S., Moldes, A.B., Domínguez, J.M., 2007. Simultaneous lactic acid and xylitol production from vine trimming wastes. J. Sci. Food Agric. 87, 1603-1612. 
Rivas, S., Conde, E., Moure, A., Domínguez, H., Parajó, J.C., 2013. Characterization, refining and antioxidant activity of saccharides derived from hemicelluloses of wood and rice husks. Food Chem. 141, 495-502.

Romaní, A., Garrote, G., Alonso, J.L., Parajó, J.C., 2010. Bioethanol production from hydrothermally pretreated Eucalyptus globulus wood. Bioresour. Technol. 101, 8706-8712.

Romaní, A., Garrote, G., López, F., Parajó, J.C., 2011. Eucalyptus globulus wood fractionation by autohydrolysis and organosolv delignification. Bioresour. Technol. 102, 5896-5904.

Romaní, A., Tomaz, P.D., Garrote, G., Teixeira, J.A., Domingues, L., 2016. Combined alkali and hydrothermal pretreatments for oat straw valorization within a biorefinery concept. Bioresour. Technol. 220, 323-332.

Ruiz, H.A., Rodríguez-Jasso, R.M., Fernandes, B.D., Vicente, A.A., Teixeira, J.A., 2013. Hydrothermal processing, as an alternative for upgrading agriculture residues and marine biomass according to the biorefinery concept: a review. Renew. Sustain. Energy Rev. 21, 35-51.

Sánchez-Gómez, R., Sánchez-Vioque, R., Santana-Méridas, O., Martín-Bejerano, M., Alonso, G.L., Salinas, M.R., Zalacain, A., 2017. A potential use of vine-shoot wastes: the antioxidant, antifeedant and phytotoxic activities of their aqueous extracts. Ind. Crops Prod. 97, 120-127.

Santos, J.I., Fillat, U., Martín-Sampedro, R., Ballesteros, I., Manzanares, P., Ballesteros, M., Eugenio, M.E., Ibarra, D., 2015. Lignin-enriched fermentation residues from bioethanol production of fast-growing poplar and forage sorghum. Bioresour 10 (3), 5215-5232.

Silva-Fernandes, T., Duarte, L.C., Carvalheiro, F., Marques, S., Loureiro-Dias, M.C. Fonseca, C., Gírio, F., 2015. Biorefining strategy for maximal monosaccharide recovery from three different feedstocks: Eucalyptus residues, wheat straw and olive tree pruning. Bioresour. Technol. 183, 203-212.

Singhvi, M.S., Chaudhari, S., Gokhale, D.V., 2014. Lignocellulose processing: a current challenge. RSC Adv. 4, 8271-8277.

Tana, T., Zhang, Z., Moghaddam, L., Rackemann, D.W., Rencoret, J., Gutiérez, A., de Río, J.C., Doherty, W.O.S., 2016. Structural changes of sugar cane bagasse lignin during cellulosic ethanol production process. ACS Sustain. Chem. Eng. 4 (10) 5483-5494.

Teixeira, A. Baenas, N., Dominguez-Perles, R., Barros, A., Rosa, E., Moreno, D.A Garcia-Viguera, C., 2014. Natural bioactive compounds from winery by-products as health promoters: a review. Int. J. Mol. Sci. 15, 15638-15678.

Vargas, F., Domínguez, E., Vila, C., Rodríguez, A., Garrote, G., 2015. Agricultura residue valorization using a hydrothermal process for second generation bioethanol and oligosaccharides production. Bioresour. Technol. 191, 263-270.

Yunus, F.-N., Nadeem, M., Rashid, F., 2015. Single-cell protein production through microbial conversion of lignocellulosic residue (wheat brand) for animal feed. J. Inst. Brew. 121 (4), 553-557. 